"Coruja de celeiro vista do lado" (Van Gogh, 1887). Esta é a imagem de capa que representa significativamente o propósito deste número 17 da Revista Abril, pelo fato de esta publicação acolher artigos, resenhas e entrevistas que abordam as literaturas de Brasil, Angola, Cabo Verde, Guiné-Bissau, Moçambique, Portugal, São Tomé e Príncipe e Goa como loci de circulação de epistemologias e pedagogias. Nesta perspectiva semiótica, a coruja - por sua natureza de visão multidirecional e elevada sabedoria pode sugerir tanto as percepções e as representações estético-discursivas de saberes tradicionais rurais e urbanos, como os processos educativos familiares e sociais no âmbito comparativo das Literaturas de Língua Portuguesa. Portanto, importa considerar, nesta edição, o potencial da linguagem literária para o trato artístico da diversidade de olhares, de corporeidades epistemológicas e de formas de representação. Por isso, os artigos aqui organizados privilegiam a problematização poética e ficcional das trocas político-ideológicas e socioculturais como estratégias educativas, e as releituras e reescritas de cânones literários como alternativas pedagógicas de interação, revisão e atualização de saberes, com ênfase na diversidade das relações de alteridade nos processos de configuração de sujeitos poéticos com base em diferentes raízes e matrizes étnico-raciais, políticas e estético-literárias. $\mathrm{Ou}$ seja, trata-se de uma abordagem que afirma saberes locais e globais, em suas especificidades internas e interculturais no tocante à produção artístico-literária de escritoras e escritores em seus respectivos países.

Paralelamente a esses aspectos, alguns dos textos a seguir trazem reflexões críticas que tensionam os desafios e avanços teórico-metodológicos quanto ao ensino das literaturas brasileira, angolana, cabo-verdiana, guineense, moçambicana, portuguesa, santomense e goesa na contemporaneidade, especialmente no Brasil em contextos de efetivação da Lei Educacional $n^{\circ} 10.639 / 2003$, que obriga a necessária circulação, nas escolas, de conteúdos sobre as histórias e culturas africanas e da diáspora negra, com ênfase na Literatura, entre outras áreas. Essa abertura para o universo do ensino faz-se necessária porque - a nosso ver e em concordância com o pensamento do sociólogo português Boaventura de Sousa Santos -, em 
meio a e na sequência de uma série de implicações, "a reflexão epistemológica deve incidir não nos conhecimentos em abstrato, mas nas práticas de conhecimento e seus impactos noutras práticas sociais" (A gramática do tempo, 2008, p.154). É nesse sentido que se dá o diálogo aqui proposto entre Literatura e Pedagogia: a multiplicidade das representações artístico-ficcionais de saberes e tradições da primeira podem subsidiar práticas de ensino propositivas e contra-hegemônicas com base na diversidade das formas de ser e de estar no mundo. Nessa "ecologia de saberes" (SANTOS, ibidem), tratada artística e pedagogicamente nos universos das letras e da educação, há que se considerar o ensino da Literatura, o que, nesta publicação, abre espaço para reflexões sobre aspectos práticos em sala de aula, que envolvem a "transposição didática de saberes literários" . Nestes termos de Cristina Mello, isso muito colabora com a emergência de "propostas didático-pedagógicas suscetíveis de contribuírem para a resolução de problemas que os alunos enfrentam no processo da leitura integral das obras literárias" ( $O$ ensino da literatura e a problemática dos géneros literários, 1998, p.18), assim como no processo de leitura do mundo e de suas relações sociais (etnia, gênero, raça, classe etc.), pautadas em diferentes - e, muitas vezes, divergentes - bases epistemológicas que colocam em tensão os saberes locais tradicionais em face dos saberes eurocentrados, tornados absolutos na série histórica dos processos coloniais. Também por isso, o filósofo camaronês Marcien Towa destaca a percepção clássica africana sobre o conhecimento e o ensinamento, condições humanas repletas de virtuosidades, a partir de um sábio egípcio que alertava "ao mesmo tempo, contra a certeza presunçosa e o dogmatismo":

\section{Ptah-hotep aconselha:}

Não seja imbuído de seu saber

Consulte o ignorante e o sábio

Os limites do saber não são jamais atingidos

Nenhum sábio alcança a perfeição

A verdade está mais escondida que uma pedra preciosa

No entanto, ela pode ser encontrada entre humildes de pilão.

(TOWA, A ideia de uma filosofia negro-africana, 2015, p. 37)

Em outras palavras, a atitude reflexiva suscitada pela coruja principalmente por ser esta uma ave comum a vários continentes - congrega os propósitos dos textos deste número 17, os quais analisam representações de pertencimentos, visões, vivências e aprendizados nas produções literárias de escritoras e escritores de países de língua oficial portuguesa. São saberes e epistemologias habitando as artes das letras; são as artes das letras habitando a escola. Enfim, olhares, escritas e pedagogias irmanados, do pilão à sala de aula.

Niterói, dezembro de 2016 Iris Maria da Costa Amâncio e Madalena Simões de Almeida Vaz Pinto

Organizadoras 